\title{
Surgical Management of Peripheral Ossifying Fibroma by Diode Laser
}

\author{
Sunil Kumar $\mathrm{P}^{1}$, Ramyasri $\mathrm{K}^{2}$, Mahipal $\mathrm{N}^{3}$, Rajababu $\mathrm{P}^{4}$
}

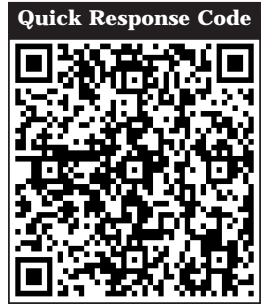

\section{doi: P10.5866/2014.611484}

${ }^{1}$ Reader

2PG Student

${ }^{3}$ Senior lecturer

${ }^{4}$ Professor and HOD

Dept. of periodontics

Kamineni institute of dental sciences

Narketpally - 508254

Nalgonda Dist. Andhra Pradesh.

\section{Article Info:}

Received: October 8, 2013

Review Completed: November 9, 2013

Accepted: December 10, 2013

Available Online: February, 2014 (www.nacd.in)

(C) NAD, 2014 - All rights reserved

Email for correspondence:

drramyaperio@gmail.com

\begin{abstract}
:
Peripheral ossifying fibroma (POF) is a solitarygrowth on the gingiva thought to arise from theperiodontal ligament constituting $9 \%$ of overall gingival growths. It is considered to be reactive in nature and postulatedto appear secondary to irritation or trauma. It is a gingival mass of fibrous connective tissue covered with a surface epithelium associated with the formation of randomly dispersed foci of a mineralized product consisting of bone, cementum-like tissue, or dystrophic calcifications having a recurrent rate of nearly $20 \%$.They usuallyoccur in young adults with a female predominance. We report a case of peripheral ossifying fibroma in a 55-year old female in the maxillary anterior region, where the surgical excision was done by using diode laser.
\end{abstract}

Key words: Periodontal ligament, pyogenic granuloma, peripheral ossifying fibroma, Diode laser.

\section{INTRODUCTION}

Localized gingival enlargements arefairly common and typically represents reactive proliferative lesions, rather than true neoplasm. ${ }^{1}$ Ossifying fibroma mostly occurs in the craniofacial bones and is generally categorized in to two types namely, central and peripheral ossifying fibroma. Central ossifying fibromas arise from the endosteum or the periodontal ligament adjacent to the root apex and causes expansion of the medullary cavity. The peripheral type occurs on the soft tissue covering the tooth bearing areas of the jaws. ${ }^{2}$ Peripheral ossifying fibromas (POF) accounts for 3.1\% of all oral lesions and $9 \%$ of gingival lesions.In 1872, Menzel first described the ossifying fibroma, but only in 1927, Montgomery assign its terminology. ${ }^{3}$

The etiopathogenesis of this tumor is not clear; however, the pluripotent cells of the periodontal ligament have the apparent ability to transform into osteoblasts, cementoblasts or fibroblasts, in response to irritants such as calculus, bacterial plaque, orthodontic appliances, illadapted crowns, and irregular restorations, 


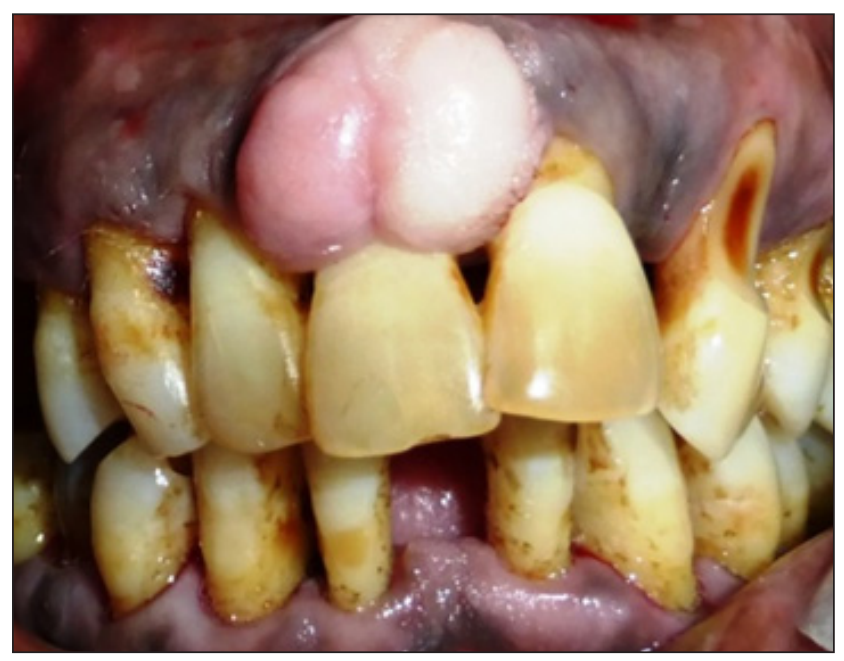

Figurel: preoperative

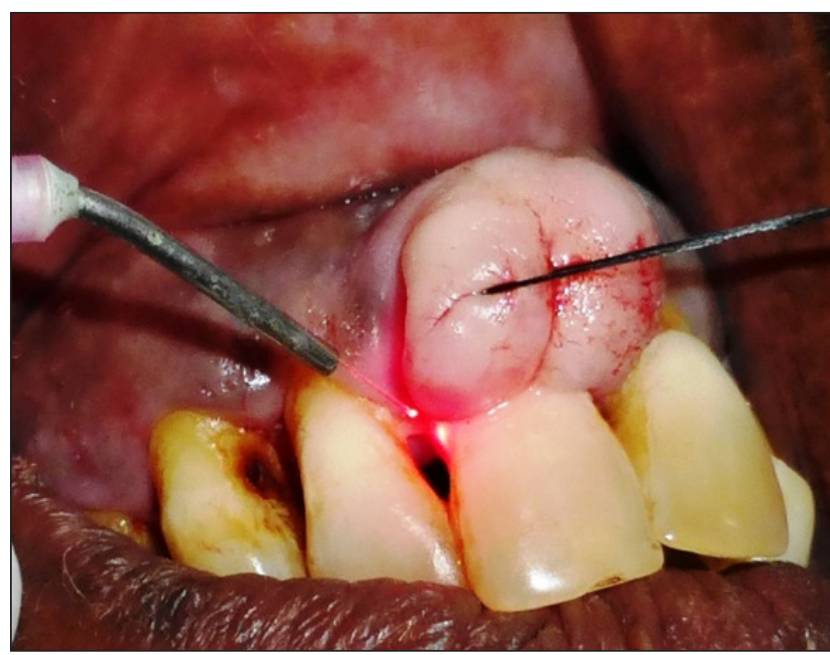

Figure 3: Excision by using laser

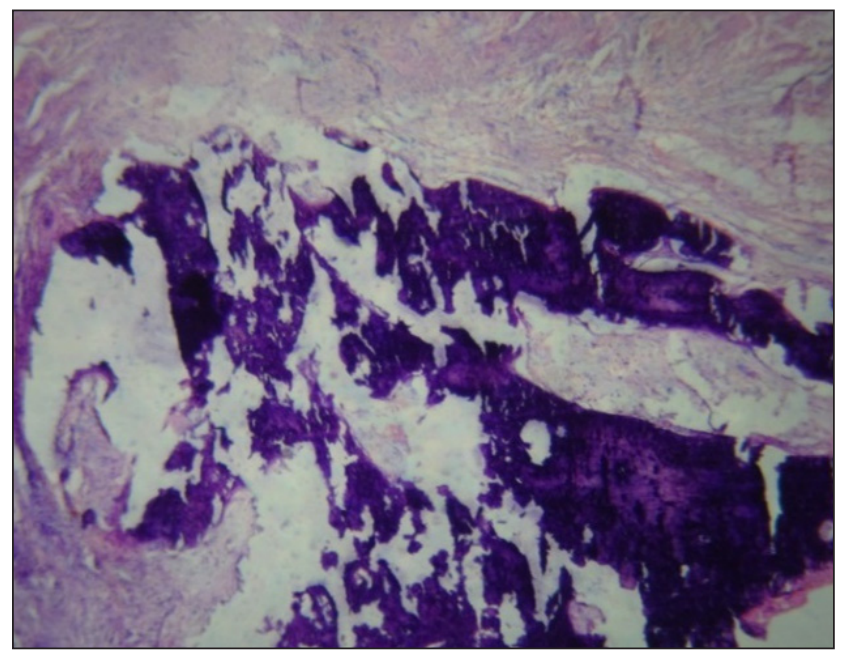

Figure 5: Histopathological picture showing Immature Bony trabeculae.

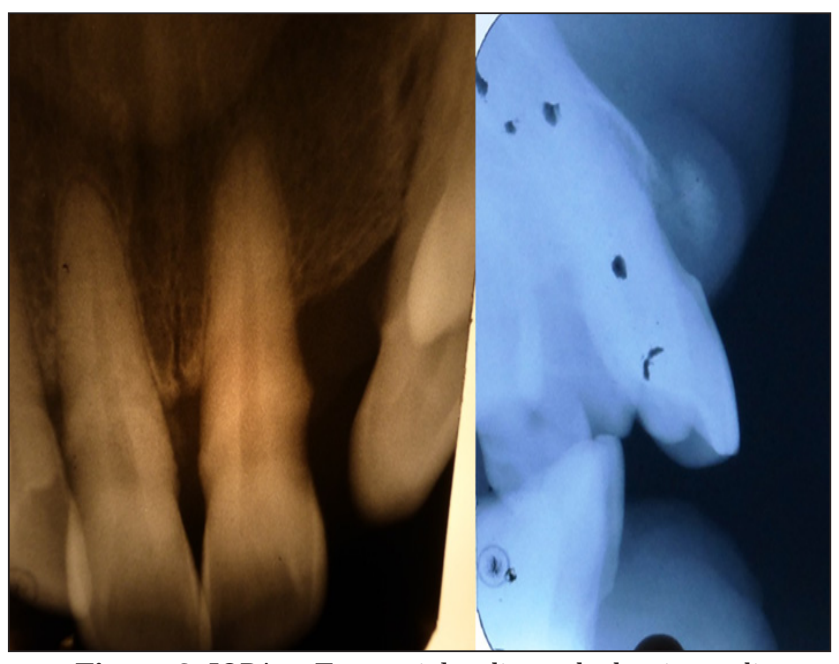

Figure 2: IOPA \& Tangential radiograph showing radio opacities in the lesion

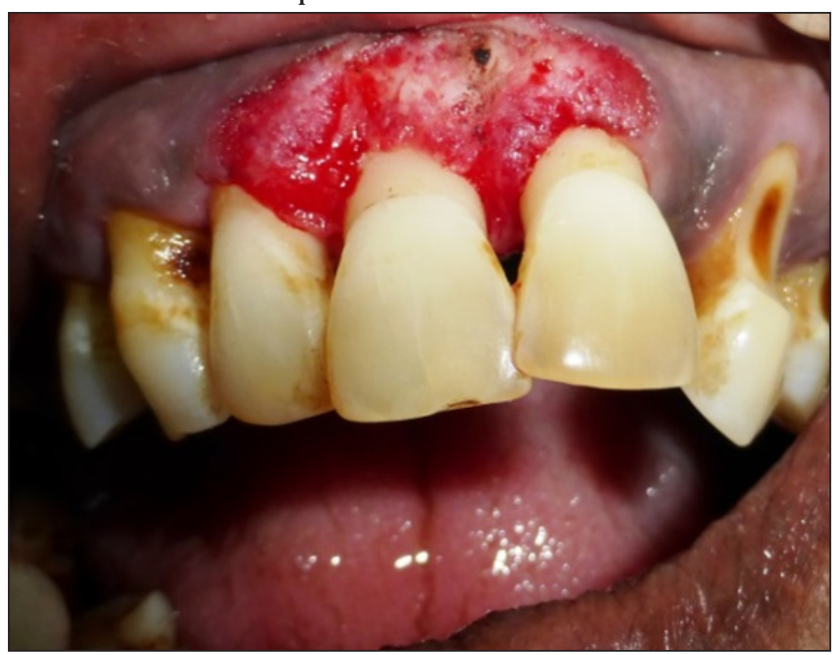

Figure 4: Immediate post-operative

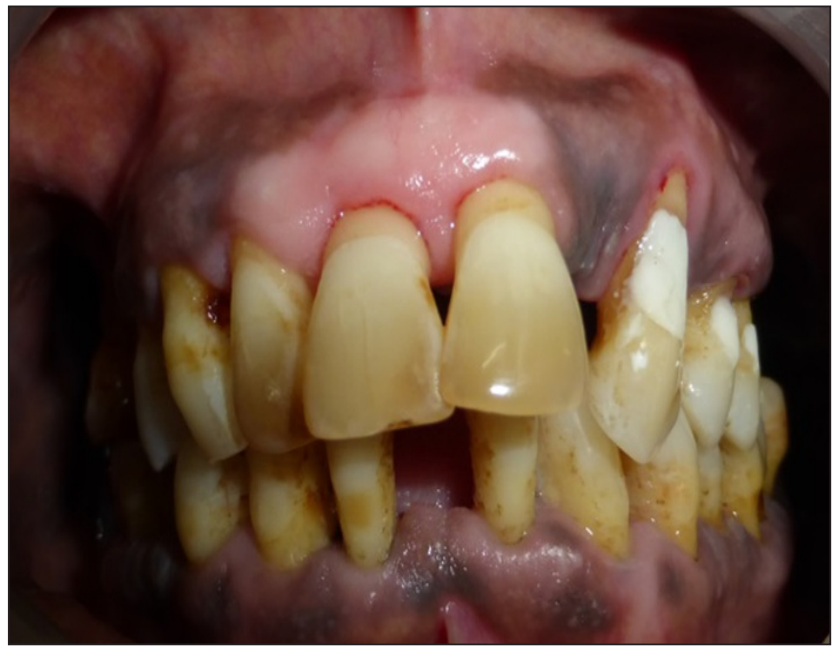

Figure 6: post-operative - 6months 
and are therefore, capable of producing a unique inflammatory hyperplasia, the peripheral ossifying fibroma. ${ }^{4,5}$

Treatment of POF includes elimination of etiological factors, scaling and root planing of involved teeth and surgical excision of Iesion. Excision should include the periodontal ligament and periosteum at the base of the lesion in order to reduce the chance of recurrence. ${ }^{5}$ Another option available in place of conventional surgical excision is the excision by using lasers for better patient acceptance and less intraoperative bleeding. Various soft tissue lasers like Nd: YAG, Argon, diode lasers are used for excision. In present case we used diode laser (Denlase - SY A.1) with wavelength of $810 \mathrm{~nm}$, which place this laser under near infrared of electromagnetic spectrum.

\section{CASE REPORT}

A55 year old female patient reported to the department of periodontics with the chief complaint of painless swelling in the upper front gum region since 1 year. Patient's history reveal ed that she had noticed the swelling 1 year back and had gradually increased in size. Patient gives history of smoking beedi since 3years.There was no history of trauma or similar growth in the past. The medical, surgical and family histories were non-contributory. Extra oral examination did not reveal any abnormalities. I ntra oral examination reveal ed a pink solitary, well defined, sessile growth in the attached gingiva is seen in relation to 11 and 21 , which is ranging of $3 \times 2 \mathrm{~cm}$ in size extending from distal surface of 11 to mesial $1 / 3^{\text {rd }}$ of 21 . Superior and inferior borders of lesion includes $1 \mathrm{~cm}$ from labial vestibule to $0.5 \mathrm{~cm}$ below the cervical margin of 11 respectively (figure 1). On palpation it was non tender and firm in consistency.

Based on the history and clinical findings differential diagnoses were considered as peripheral ossifying fibroma, peripheral odontogenic fibroma, solitary fibroma, fibrosed peripheral giant cell granuloma. Patient was subjected to routine haematological and radiographic investigations. The complete hemogram was within the normal limits.
Intraoral periapical radiograph (IOPA) did not reveal any pathological changes except for horizontal bone loss in relation to 11,21 and 22 . Then a tangential radiograph which shows the radio opacities in the soft tissue growth, it indicates the ossifications in the growth (Figure 2).

Excisional biopsy was performed by using diode laser with settings of laser in excision mode, $4 \mathrm{~W}$ power, in pulse mode and the lesion was removed along with its surrounding tissue. After excision meticulous root planing and curettage was done in relation to 11 and 21 to remove local irritants (Figure $3 \& 4)$. Histopathological examination of the specimen shows Para keratinized stratified squamous epithelium. The underlying connective tissue stroma shows fibrocellular with calcified trabeculae containing osteocytes and osteoblasts, which are frequently intermingling in immature bony trabeculae (Figure 5).

Based on the clinical, radiographic and histopathological findings, a final diagnosis of peripheral ossifying fibroma was given. The patient is on regular follow-up for the past 6 months with no signs of recurrence (Figure 6).

\section{DISCUSSION:}

ThePOF is usually arising from the interdental papilla. Most commonly in maxillary anterior region $(60 \%)$ with a female predilection,peak incidence is between second and third decade of life. It clinically presents as a nodular mass, either pedunculated or sessile. The colour ranges from red to pink, usually surface is smooth but occasionally it may ulcerated. ${ }^{\circ} \mathrm{n}$ majority of cases, there is no apparent underlying bone involvement visible on the roentgenogram. I n the present case al so no changes in the periapical radiograph were seen but tangential radiograph showed the presence of calcifications and no tooth migration was seen. A possibility of tooth migration has been reported. ${ }^{3}$

Differential diagnosis includes peripheral giant cell granuloma, pyogenic granuloma, fibroma and peripheral odontogenic fibroma, peripheral cementifying fibroma, peripheral cemento- ossifying fibroma. ${ }^{6} \mathrm{Clinically} \mathrm{granulomas} \mathrm{will} \mathrm{be} \mathrm{soft} \mathrm{in}$ 
consistency. However ossifying fibromas can only be differentiated by histological examination. They elaborate bone, cementum and spheroidal calcifications, which has given rise to various terms for these benign fibro-osseous neoplasms. When bone predominates, 'ossifying' is the appellation; while the term 'cementifying' has been assigned when curvilinear trabeculae or spheroidal calcifications are encountered.When bone and cementum-like tissues are observed, the lesions have been referred to as cemento-ossifying fibroma. ${ }^{7}$

Two schools of thought have been preferred to explain the histogenesis. The first group ofresearchers believed that POF devel ops from cells of periodontal ligament/periosteum, which hasbeen accepted by many. The widely accepted etiopathogenesis for POF is the chronic irritation of the periosteal and periodontalmembrane causes metaplasia of the connective tissue and resultant initiation of formation of bone or dystrophic calcification. ${ }^{8}$ The second group of researchers believe that POF might have developed initially as pyogenic granuloma and subsequent maturation led to the ossification of the lesion. ${ }^{9}$

As the laser excision has several advantages over conventional surgical excision like less tissue damage, Enhanced Patient comfort, Hemostasis and coagulation and better postoperative healing. ${ }^{10}$ In the present case we have used diode laser for surgical management of lesion which resulted in better patient acceptance and less discomfort to patient.

\section{CONCLUSION}

A peripheral ossifying fibroma is a slowly progressing lesion, the growth of which is generally limited. Clinically it is difficult to differentiate between most of reactive gingival lesions particularly in the initial stages. Regardless of the surgical technique employed, it is important to eliminate the etiological factors and strict postoperative followupis required because of the growth potential of incompletely removed lesions.

\section{REFERENCES}

1. Bhaskar SN, Lenin HP. Histopathology of the human gingiva (study based on 1269 biopsies) J Periodontol. 1973;44:3-17.

2. Eversole LR, Rovin S. Reactive lesions of the gingival. J Oral Pathol 1972;1: 30-38.

3. Delbem A, Cunha R, Silva J, Soubhia A. Peripheral cemento - ossifying fibroma in child. A follow up of four years report of a case. Eur J Dent 2008;2:134-137.

4. Kenney J N, Kaugars GE, Abbey L M. Comparison between the peripheral ossifying fibroma and peripheral odontogenic fibroma. J Oral Maxillofac Surg 1989;47:37882.

5. Kumar SK, Ram S, J orgensen MG, Shuler CF, Sedghizadeh PP. Multicentric peripheral ossifying fibroma. J Oral Sci 2006;48:23943.

6. Neiville BW.Damm DD,Allen CM,Bouquot J E.Text book of oral and maxillofacial pathology. $2^{\text {nd }}$ ed.philadel phia;WB Saunders co 2004;45;1-52.

7. Eversole LR, Leider AS, Nelson K. Ossifying fibroma: a clinicopathologic study of sixty-four cases. Oral Surg Oral Med Oral Pathol. 1985;60:505-511.

8. Yadav R, Gulati A. Peripheral ossifying fibroma: A case report. J Oral Sci. 2009;51:151-154.

9. Prasad S, Reddy SB, Patil SR, Kulburgi NB, Puranik RS. Peripheral Ossifying fibroma and pyogenic granuloma.Are they interrelated. N York S Dent J . 2008;74:50-52.

10. Charles M. Cobb; Lasers in Periodontics: A Review of the Literature Periodontol 2006;77:545-564.

\section{Gain quick access to our journal online View our journal at www.nacd.in}

